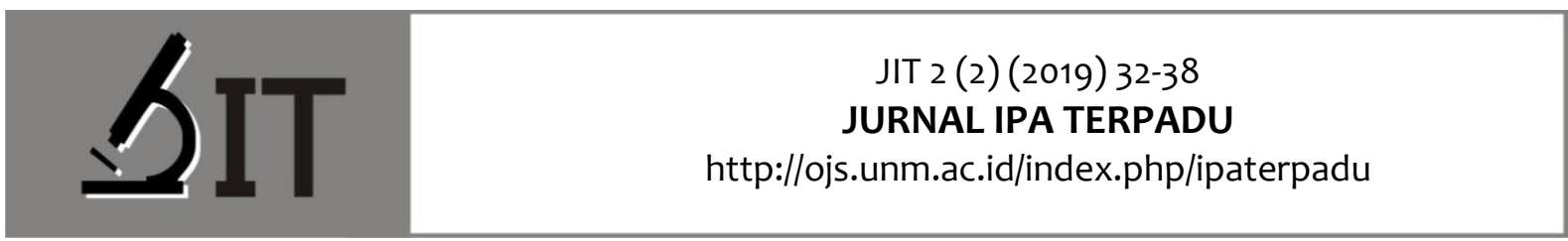

p-ISSN : 2597-8977

e-ISSN : 2597-8985

Dien Aulia Bansu*) Universitas Negeri Makassar

Ramlawat Universitas Negeri Makassa

Sitti Rahma Yunus Universitas Negeri Makassar
*) Correspondence Author: dien.aulia97@gmail.com

\section{PENGARUH METODE RESITASI TERHADAP KETERAMPILAN BERPIKIR KREATIF PESERTA DIDIK KELAS VII SMP NEGERI 7 WONOMULYO (Studi Pada Materi Pokok Sistem Organisasi Kehidupan)}

Abstrak: Penelitian ini bertujuan untuk mengetahui : (1) tingkat keterampilan berpikir kreatif peserta didik kelas VII SMPN 7 Wonomulyo yang dibelajarkan menggunakan metode resitasi berbentuk proyek pada materi pokok sistem organisasi kehidupan, (2) tingkat keterampilan berpikir kreatif peserta didik kelas VII SMPN 7 Wonomulyo yang dibelajarkan tanpa menggunakan metode resitasi berbentuk proyek pada materi pokok sistem organisasi kehidupan. (3) Pengaruh metode resitasi berbentuk proyek terhadap keterampilan berpikir kreatif peserta didik kelas VII SMPN 7 Wonomulyo pada materi pokok sistem organisasi kehidupan. Penelitian ini merupakan Quasi Experimental (eksperimen semu) dengan menggunakan desain penelitian Nonequivalent Control Group Design. Populasi penelitian ini adalah seluruh peserta didik kelas VII SMPN 7 Wonomulyo yang juga dijadikan sampel. Pengambilan sampel melalui teknik sampling jenuh dan diperoleh kelas VII A sebagai kelas eksperimen dan VII B sebagai kelas Kontrol. Instrumen penelitian keterampilan berpikir kreatif berupa soal essay berjumlah 14 item soal. Teknik pengumpulan data pada penelitian ini adalah dengan pemberian Pretest dan Posttest. Analisis data dilakukan dengan menggunakan analisis deskriptif. Statistik deskriptif untuk mengetahui hasil statistik pada skor rata-rata keterampilan berpikir kreatif. Hasil analisis deskriptif tingkat keterampilan berpikir kreatif peserta didik kelas eksperimen yang dibelajarkan menggunakan metode resitasi berbentuk proyek diperoleh rata-rata skor $\mathrm{N}$-Gain 0,46 berada pada kategori sedang, dan skor untuk kelas kontrol yang dibelajarkan menggunakan metode resitasi berbentuk soal-soal yaitu 0,26 berada pada kategori rendah. Dengan perbandingan hasil keterampilan berpikir kreatif kedua kelas maka hasil yang diperoleh telah dapat digunakan untuk mengetahui adanya pengaruh perlakuan metode resitasi tanpa menggunakan analisis statistik inferensial.

Kata Kunci: Resitasi, Keterampilan Berpikir Kreatif, Hasil Belajar.

Abstract: This study aims to find out: (1) The level of students creative thinking skills Grade VII SMPN 7 Wonomulyo taught by using the recitation project method (Study on subject matter of organizational system of life), (2) The level of students creative thinking skills Grade VII SMPN 7 Wonomulyo taught without by using the recitation project method (Study on subject matter of organizational system of life). (3) The effect of recitation project method toward students creative thinking skill Grade VII SMPN 7 Wonomulyo (Study on subject matter of organizational system of life). This research is Quasi-Experimental using the research design of Nonequivalent Control Group Design. The population of this study was all Students Grade VII SMPN 7 Wonomulyo. Sampling through Saturated Sampling technique and obtained grade VIIA as the experimental grade 
and VIIB as the Control grade. The instrument of creative thinking skills was in the form of a 14 items essay question. The technique of collecting data on this research is by Pretest and Posttest. Data analysis was performed using descriptive analysis. Descriptive statistics to find out statistical results on average creative thinking skills scores and learning outcomes. The results of a descriptive analysis of the level creative thinking skills of an experimental grade taught by using the recitation project method obtained an average $\mathrm{N}$-Gain score of 0.46 in the medium category, and the score for the control grade taught by using the recitation questions method is 0.26 was in low category. By comparing the results of creative thinking skills of both classes, the results obtained can be used to determine the effect of recitation method treatment without use of inferential statistical analysis.

Keyword: : Recitation, Creative Thinking Skills.

\section{PENDAHULUAN}

Dalam dunia pendidikan formal, pendidik dalam hal ini yaitu guru, mengajar dengan kurikulum yang terus berkembang. Saat ini telah banyak sekolah yang menggunakan Kurikulum 2013 sebagai sistem pendidikan. Kurikulum ini merupakan kurikulum tetap yang diterapkan oleh pemerintah untuk menggantikan kurikulum-2006 (KTSP). Kurikulum 2013 dirancang untuk memperkuat kompetensi peserta didik dari sisi pengetahuan, keterampilan, sikap dan perilaku secara utuh.

Mata pelajaran IPA merupakan suatu kumpulan pengetahuan yang tersusun secara sistematis, dan dalam penggunaannya secara umum terbatas pada gejala-gejala alam. IPA berkaitan dengan cara mencari tahu tentang alam secara sistematis, sehingga IPA bukan hanya penguasaan kumpulan pengetahuan yang berupa fakta-fakta, konsep-konsep atau prinsip-prinsip saja tetapi juga merupakan suatu proses penyelidikan dan penemuan.

Dalam pembelajaran IPA di sekolah khususnya jenjang SMP, peserta didik didorong untuk menemukan sendiri dan mentransformasikan informasi kompleks, mengecek informasi baru dengan aturan-aturan lama di dalam pikirannya, dan merevisinya apabila aturan-aturan itu tidak lagi sesuai. Agar benar-benar memahami dan dapat menerapkan pengetahuan, peserta didik perlu didorong untuk bekerja memecahkan masalah, diarahkan pada pengalaman belajar untuk membuat dan merancang suatu karya melalui penerapan konsep IPA dan belajar secara langsung melalui eksperimen untuk menyelidiki suatu peristiwa alam agar peserta didik menjadi aktif, keatif, dan memiliki sifat ilmiah (Mulyanratna, 2013).

Setelah melakukan observasi di SMPN 7 Wonomulyo dengan cara mewawancarai guru IPA khususnya kelas VII tahun 2017, peneliti memperoleh informasi bahwa salah satu materi yang sulit dimengerti adalah materi Sistem Organisasi Kehidupan. Pendidik di SMPN 7 Wonomulyo masih menggunakan metode pembelajaran yaitu metode ceramah dan sesekali berdiskusi. Namun masalah yang dihadapi adalah rendahnya hasil belajar peserta didik yang dikarenakan minat belajar peserta didik masih rendah dan sebagian dari peserta didik kurang memperhatikan guru saat proses pembelajaran. Peserta didik masih ribut dan terkadang bermain dalam kelas saat pembelajaran berlangsung sehingga hal tersebut mempengaruhi peserta didik yang lainnya untuk tetap fokus dalam pembelajaran. Standar nilai kriteria ketuntasan minimum (KKM) strata kelas VII yaitu 70, namun hasil belajar peserta didik yang diperoleh sebelumnya dikatakan masih banyak (60\% peserta didik) yang belum mencapai nilai standar KKM pada mata pelajaran IPA. 
Salah satu hambatan pada pelajaran IPA khususnya materi Sistem Organisasi Kehidupan adalah peserta didik kurang tertarik dengan pelajaran tersebut. Hal ini dikarenakan kurangnya kesadaran peserta didik akan manfaat dan pentingnya mengetahui tentang materi yang sangat dekat dengan kehidupannya. Menurut Karina (2017), minat belajar berperan penting dalam menentukan hasil belajar peserta didik. Materi sistem organisasi kehidupan membahas tentang tingkat hierarki, dimana sel merupakan penyusun utama kehidupan. Dengan mempelajari materi ini, peserta didik akan mengetahui tentang apa yang ada di dalam tubuh mereka. Peserta didik akan bersemangat jika mengetahui tujuan dari pembelajaran yang sedang mereka lakukan. Dalam pembelajaran, peserta didik menjadi kurang aktif karena hanya diajarkan tentang teori tanpa dituntut untuk mengetahui lebih mendalam tentang materi tersebut sehingga peserta didik tidak ikut berperan aktif dalam pembelajaran. Menurut Aditya (2016), proses pembelajaran yang harus dilakukan peserta didik untuk mendapatkan keterampilan, menemukan mengelola, menggunakan, dan mengkomunikasikan hal-hal yang telah ditemukan merupakan hasil belajar yang diharapkan.

Perlu adanya kegiatan aktif dari peserta didik agar dapat memahami materi pembelajaran. Tidak hanya harus melihat gambar dan kemudian menghayalkan bentuk aslinya tetapi dapat membuat suatu karangan yang dapat menjawab rasa penasaran mereka tentang materi tersebut. Dengan diterapkannya Kurikulum 2013 yang menyarankan agar kegiatan pembelajaran tidak hanya satu arah dari pendidik saja, melainkan dua arah atau timbal balik antara pendidik dan peserta didik, maka diharapkan peserta didik agar ikut aktif dalam proses pembelajaran. Ada banyak metode pembelajaran yang telah dikembangkan oleh para ahli untuk mendukung kegiatan belajar mengajar. Salah satu metode yang dapat diterapkan untuk peserta didik agar menjadi lebih aktif dalam pembelajaran adalah metode resitasi.

Dengan diterapkannya metode resitasi kepada peserta didik, maka akan memunculkan sikap aktif dari peserta didik untuk menyelesaikan tugas tersebut. Peserta didik secara bersama-sama akan memikirkan cara untuk menyelesaikan tugasnya dengan teori yang telah diperoleh pada saat proses pembelajaran. Mengaplikasikan konsep yang telah dipelajari sebelumnya dalam pengerjaan tugas proyek tanpa harus pendidik untuk ikut langsung membimbing akan membuat peserta didik bebas untuk berkreasi sehingga tanpa disadari peserta didik akan melatih kemampuan berpikir kreatifnya.

Kreativitas adalah kemampuan untuk memberikan gagasan-gagasan baru dan menerapkannya dalam pemecahan masalah. Kreativitas meliputi baik ciri-ciri aptitude seperti kelancaran, keluwesan (fleksibilitas), dan keaslian (orisinalitas) dalam pemikiran maupun ciri-ciri (non-aptitude), seperti rasa ingin tahu, senang mengajukan pertanyaan, dan selalu ingin mencari pengalaman baru. Kreativitas terletak pada kemampuan untuk melihat asosiasi antara hal-hal atau objek-objek yang sebelumnya tidak ada atau tidak tampak hubungannya (Semiawan, 1984).

Menurut Filsaim (Nurlaela, 2015), berpikir kreatif adalah proses berpikir yang memiliki ciriciri kelancaran (fluency), keluwesan (flexibility), keaslian, atau originalitas (originality). Kelancaran adalah kemampuan mengeluarkan ide atau gagasan yang benar sebanyak mungkin secara jelas. Keluwesan adalah kemampuan untuk mengeluarkan banyak ide atau gagasan yang beragam dan tidak monoton dengan melihat dari berbagai sudut pandang. Originalitas adalah kemampuan untuk mengeluarkan ide atau gagasan yang unik dan tdak biasanya, misalnya yang berbeda dari yang ada di buku atau berbeda dari pendapat orang lain. Elaborasi adalah kemampuan untuk menjelaskan faktor-faktor yang mempengaruhi dan menambah detail dari ide atau gagasannya sehingga lebih bernilai. Berpikir kreatif diartkan sebagai suatu kegiatan mental yang digunakan seorang untuk membangun ide atau gagasan yang baru secara fasih (fluency) dan fleksibel (flexibility). 


\section{METODE}

Penelitian ini merupakan jenis penelitian eksperimen semu (quasi experiment) rancangan pretest posttest nonequivalent control group design, dengan tujuan untuk mengetahui pengaruh metode resitasi terhadap keterampilan berpikir kreatif peserta didik kelas VII SMPN 7 Wonomulyo sebanyak 58 peserta didik yang terbagi menjadi dua kelas yaitu kelas eksperimen dan kelas kontrol.

Penelitian dilaksanakan di SMPN 7 Wonomulyo tahun ajaran 2018/2019. Populasi penelitian adalah seluruh peserta didik kelas VII yang terdiri 2 kelas dan dilakukan pemilihan sampel secara Sampling Jenuh, dimana sampel adalah kelas $\mathrm{VII}_{\mathrm{A}}$ sebagai kelas eksperimen sebanyak 29 orang dan $\mathrm{VII}_{\mathrm{B}}$ sebagai kelas kontrol sebanyak 29 orang.

Teknik pengumpulan data dilakukan dengan pemberian (pretest posttest) berupa tes keterampilan berpikir kreatif berbentuk essay. Instrumen yang digunakan adalah tes keterampilan berpikir kreatif berjumlah 14 butir. Data yang diperoleh dianalisis secara statistik deskriptif.

\section{HASIL DAN PEMBAHASAN}

\section{Hasil Penelitian}

\section{a. Analisis Statistik Deskriptif}

\section{1) Deskripsi Skor Pretest-Posttest keterampilan berpikir kreatif peserta didik}

Hasil analisis statistik keterampilan berpikir kreatif peserta didik kelas VII SMPN 7 Wonomulyo, yaitu sebelum dan setelah dibelajarkan dengan menggunakan metode resitasi berbentuk proyek dan yang diajar menggunakan metode resitasi berbentuk soal-soal, diperoleh skor pretest dan posttest pada kelas kontrol dan eksperimen untuk materi pokok sistem organisasi kehidupan dapat dilihat pada Tabel 1.

Tabel 1. Statistik Deskriptif Skor Pretest dan Posttest Keterampilan Berpikir Kreatif Peserta Didik Kelas Eksperimen dan Kelas Kontrol

\begin{tabular}{cccccc}
\hline & & \multicolumn{2}{c}{ Kelas Eksperimen } & \multicolumn{2}{c}{ Kelas Kontrol } \\
\cline { 3 - 6 } No. & Statistik & Pretest & Posttest & Pretest & Posttest \\
\cline { 3 - 6 } & & 29 & 29 & 29 & 29 \\
\hline 1. & Jumlah sampel & 100 & 100 & 100 & 100 \\
2. & Skor Maksimal & 0 & 0 & 0 & 0 \\
3. & Skor Minimal & 44 & 74 & 62 & 72 \\
4. & Skor tertinggi & 20 & 44 & 6 & 24 \\
5. & Skor terendah & 31,52 & 62,83 & 28,07 & 46,86 \\
6. & Skor rata-rata & 5,65 & 6,92 & 10,27 & 10,60 \\
7. & Standar deviasi & & & & \\
\hline
\end{tabular}

Berdasarkan Tabel 1.1 hasil analisis statistik deskriptif dapat dideskripsikan hasil pretest keterampilan berpikir kreatif pada kelas eksperimen yang merupakan kelas dengan adanya perlakuan resitasi, diperoleh skor rata-rata peserta didik 31,52 dengan standar deviasi 5,65. Skor tertinggi yang diperoleh 44 dan skor terendah 20 dengan skor total tertinggi yaitu 100. Hasil posttest keterampilan berpikir kreatif pada kelas eksperimen, diperoleh skor rata-rata peserta didik 62,83 dengan standar deviasi 6,92. Skor tertinggi yang diperoleh 74 dan skor terendah 44 dengan skor total tertinggi yaitu 
100. Hasil pretest keterampilan berpikir kreatif pada kelas Kontrol, diperoleh skor ratarata peserta didik 28,07 dengan standar deviasi 10,27. Skor tertinggi yang diperoleh yaitu 62 dan skor terendah yaitu 6 dengan skor total tertinggi 100. Hasil posttest keterampilan berpikir kreatif pada kelas kontrol, diperoleh skor rata-rata peserta didik 46,86 dengan standar deviasi 10,60. Skor tertinggi yang diperoleh 72 dan skor terendah 24 dengan skor total tertinggi 100.

\section{b. Analisis N-Gain}

Setelah diperoleh nilai pretest dan posttest dari kedua kelas penelitian, dapat dilakukan uji $\mathrm{N}$-Gain untuk mengetahui tingkat keterampilan berpikir kreatif peserta didik seperti pada Tabel 2.

Tabel 2. Rata-Rata N-Gain Tes Keterampilan Berpikir Kreatif Kelas Eksperimen dan Kelas Kontrol

\begin{tabular}{ccccc}
\hline \multirow{2}{*}{ Kelas } & \multicolumn{2}{c}{ Skor } & Rata-Rata Skor N- & \multirow{2}{*}{ Kategori } \\
& Pre-Test & Post-Test & Gain & \\
\hline Kelas Eksperimen & 31.52 & 62.83 & 0.46 & Sedang \\
Kelas Kontrol & 28.07 & 46.86 & 0.26 & Rendah \\
\hline
\end{tabular}

Berdasarkan data Tabel 2 deskripsi kategori N-Gain keterampilan berpikir kreatif peserta didik, kelas eksperimen berada pada kategori sedang dengan skor N-Gain 0,46. Sedangkan untuk kelas kontrol berada pada kategori rendah dengan skor N-Gain 0,26.

\section{c. Peningkatan Tiap Indikator}

Hasil belajar peserta didik pada materi sistem organisasi kehidupan pada kelas eksperimen dan kontrol dapat dilihat dari N-gain tiap indikatornya. Berikut disajikan Tabel 3.

Tabel 3. Skor N-gain Setiap Indikator Kelas Eksperimen dan Kelas Kontrol Pada Materi Pokok Sistem Organisasi Kehidupan

\begin{tabular}{clcccc}
\hline \multirow{2}{*}{ No } & \multicolumn{1}{c}{ Indikator } & Jumlah & \multicolumn{2}{c}{ Pencapaian } & n-gain \\
\cline { 4 - 5 } & & soal & Eksperiment & Kontrol \\
\hline 1 & Fluency (Permulaan Kata) & 3 & 0,71 & 0,62 \\
2 & Fluency (Menyusun Kata) & 2 & 0,82 & 0,26 \\
3 & $\begin{array}{l}\text { Fluency (Sifat-sifat yang sama) } \\
\text { Flexibilty dan Originality (Penggunaan }\end{array}$ & 3 & 0,59 & 0,32 \\
4 & $\begin{array}{l}\text { luar biasa) } \\
\text { Fluency dan Elaboration (Apa }\end{array}$ & 3 & 0,008 & 0,07 \\
5 & $\begin{array}{l}\text { Akibatnya) } \\
\text { Rata-Rata }\end{array}$ & 3 & 0,34 & 0,12 \\
\hline & & $\mathbf{0 , 4 9}$ & $\mathbf{0 , 2 8}$ \\
\hline
\end{tabular}

Berdasarkan Tabel 3 skor $\mathrm{N}$-Gain setiap indikator keterampilan berpikir kreatif berjumlah 5 indikator dengan jumlah soal yang berbeda. Rata-rata skor N-Gain yang diperoleh yaitu 0,49 dan berada pada kategori sedang. Pada kelas kontrol pencapain indikator keterampilan berpikir kreatif diperoleh rata-rata skor $\mathrm{N}$-Gain yaitu 0,28 dan berada pada kategori rendah. 


\section{Pembahasan}

Setelah dilakukan penelitian pada materi pokok sistem organisasi kehidupan dapat diketahui bahwa keterampilan berpikir kreatif peserta didik yang dibelajarkan dengan metode resitasi berbentuk proyek lebih tinggi dibandingkan dengan keterampilan berpikir kreatif peserta didik yang diajarkan dengan metode resitasi berbentuk soal-soal. Hal ini disebabkan oleh adanya resitasi yang berbeda pada masing-masing kelas. Dengan pemberian resitasi disetiap akhir pembelajaran telah membuat peserta didik lebih aktif dalam pembelajaran.

Hasil analisis deskriptif keterampilan berpikir kreatif dengan menggunakan rumus $\mathrm{N}$-gain pada kelas eksperimen diperoleh skor 0.46 termasuk pada kategori sedang. Dan kelas kontrol diperoleh skor 0.26 termasuk pada kategori rendah. Menurut Jagom (2015), dengan kreativitas yang dimiliki seseorang dapat mewujudkan dirinya sehingga lancar dan luwes dalam berpikir dan dapat melihat masalah dari berbagai sudut pandang.

Pencapaian indikator keterampilan berpikir kreatif pada kelas eksperimen dan kelas kontrol dimana indikator soal yaitu, indikator 1 Fluency (Permulaan Kata), indikator 2 Fluency (Menyusun Kata), indikator 3 Fluency (Sifat-sifat yang sama), indikator 4 Flexibilty dan Originality (Penggunaan luar biasa) dan indikator 5 Fluency dan Elaboration (Apa Akibatnya). Pada kelas eksperimen skor $\mathrm{N}$ gain untuk indikator 1 dan 2 berada pada kategori tinggi dengan skor 0.71 dan 0.82 . Skor $\mathrm{N}$-gain untuk indikator 3 dan 5 berada pada kategori sedang dengan skor 0.59 dan 0.34. Dan skor N-gain untuk indikator 4 berada pada kategori rendah dengan skor 0.008. Pada indikator 4 Flexibility dan Originality (penggunaan luar biasa), skor $\mathrm{N}$-Gain kelas eksperimen lebih rendah dibandingkan kelas kontrol yang memiliki skor 0.07. Hal ini disebabkan karena peserta didik cenderung dilatih pada hafalan dan mencari satu jawaban yang benar terhadap soal-soal yang diberikan. Pada indikator 4 membahas tentang soal yang jawabannya bukan merupakan jawaban yang selama ini diketahui atau dipikirkan. Jawaban yang dibutuhkan di indikator 4 adalah jawaban yang lain daripada yang lain atau penggunaan benda dalam fungsi yang lainnya. Mencari jawaban yang lain seperti ini yang jarang dilatihkan kepada peserta didik sehingga membuat hasil keterampilan berpikir kreatif pada indikator 4 menjadi rendah.

Pencapaian setiap indikator pada kelas kontrol masuk pada kategori rendah. Pada indikator 1 dan 3 masuk pada kategori sedang dengan skor $\mathrm{N}$-gain 0.62 dan 0.32. sedangkan untuk indikator 2, 4 dan 5 masuk pada kategori rendah. Hal ini disebabkan oleh proses-proses pemikiran tinggi termasuk berpikir kreatif tidak dilatihkan. Kecenderungan kuat ke arah penstereotipan (klise), seakan-akan perilaku orisinil atau yang "lain daripada yang lain" dirasakan sebagai sesuatu yang aneh. Menurut Kenedi (2017), faktor kreativitas peserta didik berpengaruh terhadap peningkatan hasil belajar. Semakin kreatif seseorang dalam belajar maka hasil belajar yang akan dicapaianya juga semakin baik.

\section{KESIMPULAN}

Berdasarkan hasil penelitian dan pembahasan dapat disimpulkan sebagai berikut:

1. Tingkat keterampilan berpikir kreatif peserta didik kelas VII SMPN 7 Wonomulyo yang diajarkan menggunakan metode resitasi berbentuk proyek pada materi sistem organisasi kehidupan berada pada kategori sedang.

2. Tingkat keterampilan berpikir kreatif peserta didik kelas VII SMPN 7 Wonomulyo yang diajarkan tanpa menggunakan metode resitasi berbentuk proyek pada materi sistem organisasi kehidupan berada pada kategori rendah.

3. Terdapat pengaruh metode resitasi berbentuk proyek terhadap keterampilan berpikir kreatif peserta didik kelas VII SMPN 7 Wonomulyo pada materi pokok sistem organisasi kehidupan. 


\section{DAFTAR PUSTAKA}

Aditya, D. Y. (2016). Pengaruh Penerapan Metode Pembelajaran Resitasi Terhadap Hasil Belajar Matematika Siswa. Jurnal SAP, Volume 1 Nomor 2, 165-174.

Jagom, Y. O. (2015). Kreativitas Siswa SMP dalam Menyelesaikan Masalah Geometri Berdasarkan Gaya Belajar Visual-Spatial dan Auditory-Sequental. Jurnal Pendidikan Matematika, Volume 1 Nomor 3, 176-189.

Karina, R. M., Syafrina, A., \& Habibah, S. (2017). Hubungan Antara Minat Belajar dengan Hasil Belajar Siswa Dalam Mata Pelajaran IPA Pada Kelas V SD Negeri Garot Geuceu Aceh Besar. Jurnal Ilmiah Pendidikan Guru Sekolah Dasar, Volume 2 Nomor 1. Hal 61-77.

Kenedi. (2017). Pengembangan Kreativitas Siswa Dalam Proses Pembelajaran Di Kelas II SMP Negeri 3 Rokan IV Koto. Jurnal Ilmu Pendidikan Sosial, Sains, dan Humaniora, Volume 3 Nomor 2: 329-347.

Mulyanratna, M. (2013). Pengaruh Pemberian Tugas Testruktur dalam Model Pembelajaran Kooperatif tipe STAD terhadap Hasil Belajar SIswa pada Materi Fluida Statis di Kelas XI IPA SMPN 1 Masapati. Inovasi Pendidikan Fisika, 49-54.

Nurlaela, L., \& Ismayati, E. (2015). Strategi Belajar Berpikir Kreatif. Yogyakarta: Penerbit Ombak.

Semiawan, C., Munandar, A., \& Munandar, S. (1984). Memupuk Bakat Dan Kreativitas Siswa Sekolah Menengah. Jakarta: PT. Gramedia.

Received, 21 November 2018

Accepted, 3 Januari 2019

\section{Dien Aulia Bansu}

Mahasiswa Program Studi Pendidikan IPA FMIPA UNM, aktif melakukan penelitian pada bidang Pendidikan IPA, dapat dihubungi melalui pos-el: dien.aulia97@gmail.com

\section{Ramlawati}

Dosen Program Studi Pendidikan IPA FMIPA UNM, aktif melakukan penelitian pada bidang pendidikan IPA.

\section{Sitti Rahma Yunus}

Dosen Program Studi Pendidikan IPA FMIPA UNM, aktif melakukan penelitian pada bidang pendidikan IPA. 